\title{
Hvad har organisationskultur og ESDH med hinanden at gøre?
}

\author{
Af Vibeke Højmark Larsen
}

\section{Introduktion}

Elektronisk sags- og dokumenthåndtering, i daglig tale ESDH, er et aspekt af området digital forvaltning, som er kåret til at være et af informationsspecialisternes nye arbejdsområder. ESDH hører til gruppen af systemer, værktøjer og processer til dokument- og videnstyring, og det er informationsspecialister uddannet til at håndtere. I princippet består ESDH af elektronisk dokumenthåndtering koblet sammen med sagsbegrebet fra den offentlige forvaltning. Fordelene ved ESDH er blandt andet, at man kan styre, behandle og dele information på tværs af organisationen. Al information er elektronisk tilgængelig for alle. Ifølge Steinmark \& Zangenberg (1998, s. 19), er elektronisk dokumenthåndtering "en samlebetegnelse for systemer og processer, der tillader en organisation at arbejde med dokumenter uden de begrænsninger, der er knyttet til papirbaserede dokumenter". Ud fra denne definition ses en tydelig forskel mellem den traditionelle måde at håndtere dokumenter på i organisationen og den elektroniske. Forskellen medfører, at organisationens arbejdsprocesser i højere grad påvirkes af systemet. Hertil kommer sagshåndtering, som indebærer en yderlige- re ændring i arbejdsprocesserne, så vi fremover taler om digital journalisering, elektronisk lagring samt udveksling og arkivering af sager.

Ændringerne i arbejdsprocesserne betyder at ESDH ikke kun handler om teknologi, men også om de mennesker der skal bruge systemerne samt de organisationer, hvori de indgår. Hvis vi skal forstå, hvordan ny teknologi påvirker og er påvirket af organisationer er det i følge organisationskulturteoretikeren Schein (1994, s. 2) nødvendigt med en kulturanalyse. Organisationskultur bliver således et centralt begreb i forbindelse med ESDH. Denne synsvinkel støttes også af Cooper (1994), Robey \& Azevedo (1994) og Hoffman \& Klepper (2000).

Denne artikel omhandler to aspekter af ESDH: 1) implementering af ESDH og 2) kulturen omkring anvendelsen af den type systemer. Gennem et casestudie vedrørende implementering og anvendelse af ESDH i en offentlig virksomhed har artiklen til formål at tydeliggøre, hvordan organisationskultur og selve implementeringsprojektet påvirker anvendelsen af systemer som ESDH. Artiklen bygger på 
et kandidatspeciale fra Danmarks Biblioteksskole (Højmark Larsen, 2003).

\section{Casestudie i implementering og anvendelse af ESDH hos en offentlig virksomhed}

Undersøgelsen foregik i en offentlig virksomhed, hvor man havde observeret en uhensigtsmæssig adfærd omkring anvendelsen af deres ESDH-system. Undersøgelsen bestod $\mathrm{i}$ et eksplorativt, kvalitativt single-casestudie, der havde til formål at eksemplificere organisatoriske aspekter af implementering og anvendelse af ESDH-systemer. Et single-casestudie blev valgt for at få mulighed for at komme i dybden med casen, fremfor at komme med nomotetiske lovmæssigheder. Ved casestudier anvendes ofte følgende 4 metoder: observation, interview, gruppediskussion, historisk studie (Gorman \& Clayton, 1997); i dette studie blev der anvendt observation og semistrukturerede interviews (med udgangspunkt i en interviewguide) samt et historisk studie af organisationsdokumenter. Sidstnævnte kan bla. supplere interviewdata. "Generelt har vi alle en tendens til at beskrive tidligere hændelser og hændelsesforløb som mere rationalistiske, end de egentlig var" (Andersen, 1997, s. 161). Her kan historiske dokumenter supplere de interviewedes hukommelse.

Virksomheden er karakteriseret ved, at den ledes af en direktion efter principperne for værdibaseret ledelse. Det centrale ved værdibaseret ledelse er, at organisationer styrer efter værdier frem for regler. Det betyder, at medarbejderne og ledelsen forvalter deres arbejdsopgaver ud fra vedtagne værdier. Der er ca. 180 medarbejdere i virksomheden, hvoraf en stor del af dem er sagsbehandlere. Organisationsstrukturen er forholdsvis flad (3 lag) og funktionsopdelt i de funktioner, som hver afdeling udfører (Hatch, 2001, s. 207). Det er for hver afdeling defineret hvilke arbejdsopgaver og funktioner, der skal løses. Det kan nævnes, at virksomheden også arbejder med projektorganisering på tværs af afdelingerne. Virksomheden er underlagt diverse love omkring forvaltning, men også love med krav til bl.a. arkiver og registre. Lovgivningen er med til at sætte rammerne for sags- og dokumenthåndteringen og påvirker såvel ledelsens styring af sagsbehandling som medarbejdernes sagsbehandling. Det er i den forbindelse vigtigt, at virksomheden kan dokumentere sit arbejde i forhold til det offentlige og offentligheden (borgerne).

Et ESDH-system blev indkøbt i 1997 og anvendes i sagsbehandlingen. Anvendelsen har dog vist sig at være karakteriseret ved uhensigtsmæssige adfærdsmønstre, som ledelsen tilsyneladende har fuldt kendskab til. På baggrund af casestudiet blev følgende uhensigtsmæssigheder identificeret:

- Manglende kendskab til ESDH-systemet hos ledelsen og hos medarbejderne.

- Journalmedarbejdere både indskanner og kopierer indgående post i ESDH-systemet, og kopierne bliver sendt til sagsbehandlerne, som samtidig har adgang til den elektroniske version.

- Brug af private pc-drev i stedet for ESDH, som kan ses som "privatarkiver", dvs. medarbejdernes egne arkivsystemer. Sagsdokumenter bliver ofte gemt på medarbejderens private drev på pc'en, i hvert fald indtil de er klar til f.eks. at blive sendt ud eller måske endda først, når sagen er afsluttet. Det gør det ikke muligt for kolleger og ledelse at følge sagens gang. Når dokumenter først præsenteres for andre, når det er helt færdigt, er det ikke muligt at få indsigt i sagsbehandlingsprocessen, men kun det færdige produkt. Det er heller ikke muligt at få indblik i sagens status, når det er usikkert hvorvidt alle dokumenter er indlagt i sagen. Det er sågar ikke muligt at finde ud af, om sagsbehandleren allerede er i gang med at besvare en henvendelse, når det foreløbige dokument ikke er vedhæftet sagen.

- Forskellige arbejdsgange for sagsbehandling finder sted i afdelingerne, herunder forskellige arbejdsgange for brugen af ESDH.

- Tidsfrister styres i høj grad af den enkelte medarbejder i deres private kalendere. Den funktion i ESDH-systemet, som er beregnet på at styre dette, bruges tilsyneladende ikke. 
Det er bare nogle af problemerne ved anvendelsen af ESDH-systemet, som forhindrer virksomheden i at opnå alle fordelene ved ESDH. Mest væsentligt er det, at borgerbetjeningen ikke er så kvalitativ og effektiv, som ESDH giver mulighed for.

Kort sagt er adfærden hos caseobjektet præget af dobbeltarbejde. Der er intet logisk grundlag for adfærden, hvorfor det var interessant at se nærmere på hvordan den er opstået og hvorfor.

Undersøgelsesresultaterne baserer sig på analyser af dokumenter fra implementeringen af ESDH-systemet, interne og eksterne dokumenter fra virksomheden og på interviews af udvalgte ledere og medarbejdere $\mathrm{i}$ virksomheden.

ESDH-systemet blev indkøbt omkring 1997, og for at finde ud af hvor den uhensigtsmæssige adfærd havde sit udspring, var det relevant retrospektivt at se på det projekt, som havde stået for implementeringen af systemet. Formålet var at identificere, hvilke forandringer der var sket som følge af implementeringen og hermed opnå en forståelse af udgangspunktet for kulturen omkring ESDH-systemet hos caseobjektet. Det grundlæggende spørgsmål var:
- Hvordan har implementeringen af ESDH påvirket kulturen omkring anvendelsen af systemet?

Analysen af implementeringsprojektet blev foretaget ud fra Leavitts (1965) teori og model om organisationsudvikling (Figur 1) og fokuserede på mulige barrierer for implementeringen.

Efterfølgende blev det ud fra Scheins (1994) teori og model for organisationskultur (Figur 2) analyseret, hvilken kultur der eksisterer omkring anvendelsen $\mathrm{i}$ dag.

Analysen tog udgangspunkt i følgende spørgsmål:

- Hvilken organisationskultur kan identificeres hos caseobjektet i forhold til anvendelsen af ESDH?

- Hvordan kan en analyse af organisationskulturen forklare den uhensigtsmæssige adfærd hos caseobjektet?

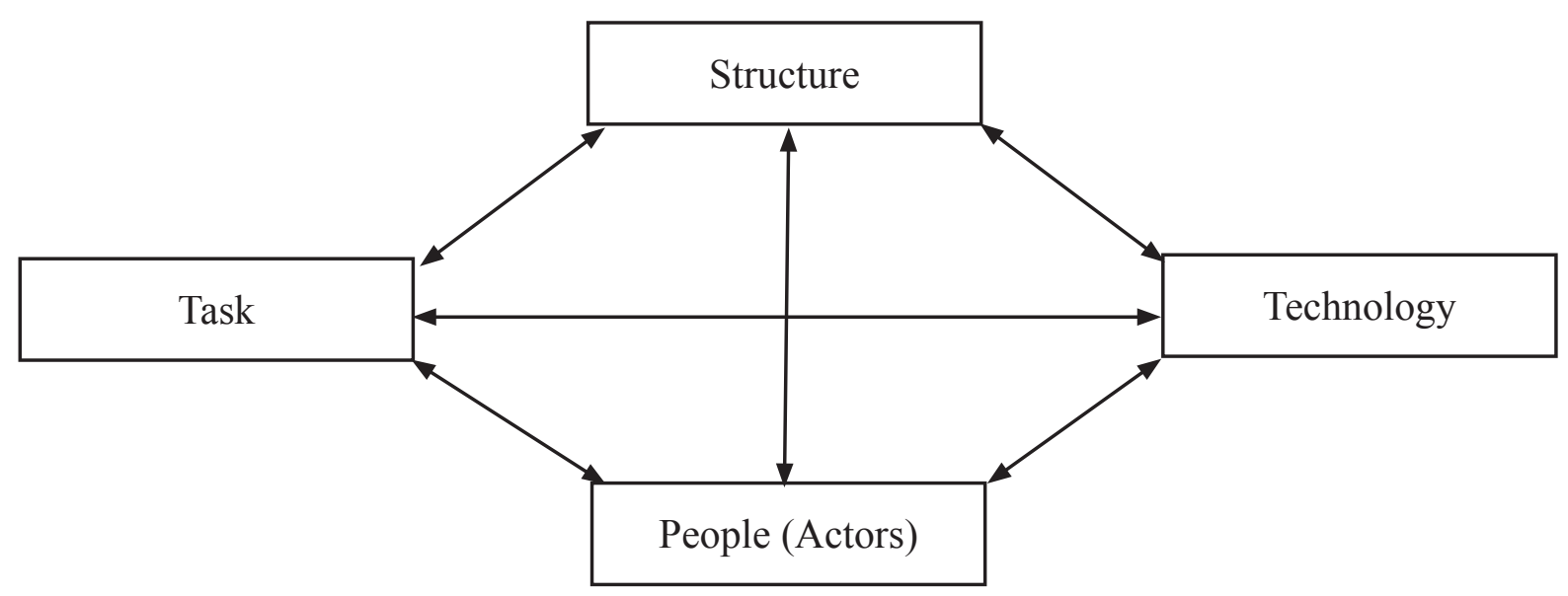

Figur 1. Leavitts organisationsmodel (1965) 


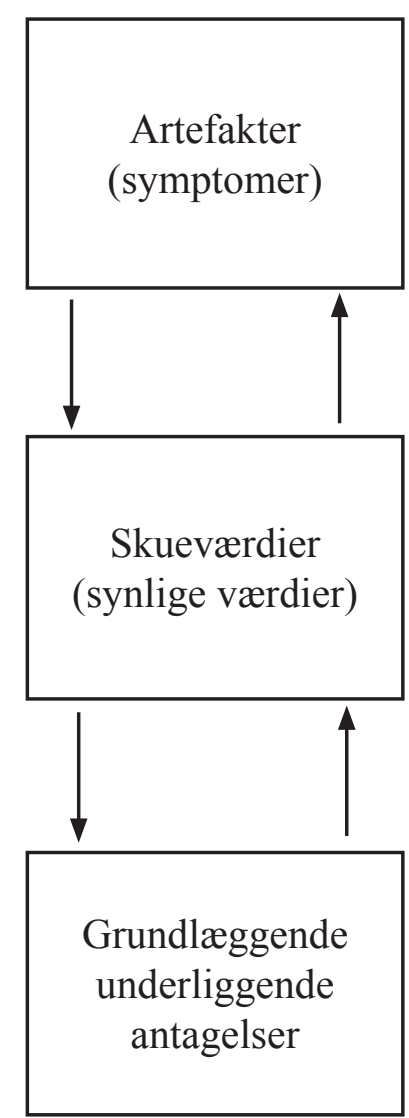

Synlige organisatoriske strukturer og processer (Vanskelige at tyde)

Strategier, mål og filosofier (Synlige begrundelser)

Ubevidste, »tagesfor-givet« anskuelser, opfattelser, tanker og følelser (Ultimativ kilde til værdier og handling)

Figur 2. Scheins tre kulturniveauer, som danner grundlaget for kulturanalysen (1994, s.24)

Til sidst blev de to analyser sammenlignet mhp. at vurdere hvilken mulig påvirkning implementeringsprojektet havde haft på den efterfølgende anvendelse af systemet.

\section{Implementering af ESDH - hvorfor går det galt?}

Implementeringen af et ESDH-system er et stort ITprojekt med store udfordringer. Ofte griber systemet ind i hele organisationen - "en forandring i måderne at arbejde på" (Projekt Digital Forvaltning, 2002, s. 4). Man kan tale om organisatorisk implementering af ESDH-systemet, forstået af Hertzum (2002) som de aktiviteter, der forbereder organisationen og brugerne på det nye system samt forbereder systemet til overgangsperioden mellem det gamle og det nye system. Men projektet kan let komme ind i en ond cirkel, hvor folk blot ser systemet som endnu et værktøj, de skal lære, og ikke som en fordel for deres arbejde.

Leavitts organisationsmodel fra 1965 viser tydeligt, at implementering af IT som ESDH uværgeligt påvirker hele organisationen. I følge Leavitt består organisationer af 4 interagerende variable; opgaver, struktur, teknologi og aktører. Selvom det er en ældre figur, illustrerer den fint forholdet mellem implementering af IT og organisationsforandring. Hvis man forandrer en af variablerne vil det påvirke de øvrige, da de er gensidigt afhængige. Man kan sige at organisatorisk forandring er igangsat $i$ en af variablerne, f.eks. ved ændring i teknologivariablen. Det fører videre til to synspunkter omkring implementering af IT. Nogle ser implementering af IT som en måde at udvikle organisationer på; andre (f.eks. Kræmmergaard Jensen, 1999; Leavitt, 1965; Teknologirådet, 2001) ser derimod organisationsudvikling, eller organisatorisk forandring, som en nødvendighed for implementering af IT med henblik på at sikre dens fremtidige anvendelse efter implementeringsprojektet. Sikkert er det, at en forandring er uundgåelig, og forandring er kompliceret.

Implementering af IT påvirker altså organisationer, men det er i høj grad implementeringsprojektet, der påvirker den efterfølgende anvendelse af IT-systemet (Kwon \& Zmud, 1987). Der kan være flere barrierer et implementeringsprojekt, her forstået som de faktorer der påvirker projektets gennemførelse samt IT's anvendelse bagefter. Det kan være barrierer af teknisk, menneskelig eller organisatorisk karakter. Ofte fokuseres der udelukkende på tekniske faktorer, mens de organisatoriske og menneskelige barrierer alt for ofte bliver glemt (Eason, 1988). Det er derfor det ofte går galt. Trods en en stigende interesse $\mathrm{i}$ Danmarks offentlige forvaltning for organisatoriske aspekter ved IT-implementeringsprojekter, f.eks. Forskningsministeriet (1997), Projekt Digital For- 
valtning (2002) og Teknologirådet (2001), er det stadig svært at implementere og anvende ESDH.

\section{Hvorfor er det så svært at få mennesker til at an- vende informationssystemer?}

Deloitte \& Touche (Deloitte \& Touche Consulting Group, 1998) er i en undersøgelse kommet frem til, at modstand mod forandringer er den største kritiske succesfaktor for implementeringsprojekter i Danmark. Ifølge Schein (1994, s. 3) er en af de primære kilder til modstanden mod forandring kulturen. Et ESDH-system medfører forandring, dvs. udgør et opgør med en kulturs grundlæggende antagelser, hvilket indebærer en utryghed der kan føre til modstand. Det er således vigtigt at systemet "passer" til organisationens kultur (Andersen \& Nicolajsen (1999, s. 25). I følge Forskningsministeriet (1997) kan modstanden skyldes kulturen omkring information $i$ en given virksomhed. "Nogle organisationer har en kultur der bygger på holdningen om, at information og viden er personlige ressourcer, der virker som magtpositioner inden for organisationen. En sådan kultur kan betyde, at overgangen til elektronisk dokumenthåndtering, hvor information i princippet er en fri ressource, besværliggøres" (kap. 2, afs. 3). Det fører tilbage til, at ESDH ofte er ønsket om at styre, behandle og dele information på tværs af organisationen. Det vil indebære en demokratisering af informationen, som måske ikke alle er vant til eller interesseret $\mathrm{i}$.

En analyse af organisationskulturen kan i den forbindelse anvendes til at finde ud af, hvordan man motiverer medarbejdere til at anvende ESDH. En kulturanalyse kan f.eks. vise, hvor kulturen kolliderer med systemet, hvor kulturen ikke understøtter anvendelsen af ESDH, og hvor kulturen kan udnyttes til at sikre implementering og anvendelse af ESDH.

\section{En mulig metode til kulturanalyse}

Kultur defineres i Scheins teori (Schein, 1994) som et mønster af fælles grundlæggende antagelser, som 'gruppen' har lært sig mens den løste sine proble- mer med ekstern tilpasning og intern integration. Antagelserne har vist sig at fungere godt nok til at kunne betragtes som gyldige og bliver derfor viderekommunikeret til nye gruppemedlemmer som den korrekte måde at opfatte, tænke og føle på i relation til den type problemer. Herudfra handler kultur om loering og problemløsning samt hvordan kulturens medlemmer handler i de situationer. Når en organisation vælger at implementere ESDH, så skal den f.eks. lære det nye system at kende, den skal lære nye måder at gøre tingene på samt nye måder at løse problemer på. Derfor er Scheins definition af organisationskultur relevant at inddrage.

Schein arbejder med tre kulturniveauer som grundlag for at analysere kulturen (Figur 2). Kernen i en organisationskultur udgøres af et mønster af fælles grundlæggende antagelser, baseret på en analyse af de tre kulturniveauer: artefakter, skueværdier og grundlæggende antagelser.

Artefakter er det øverste kulturniveau, og det er det mest synlige, men samtidig også det sværeste at tyde. Det er "alle de fænomener, som man ser, hører og føler, når man møder en ny gruppe med en ubekendt kultur", og de vil give sig til udtryk i f.eks. "de fysiske omgivelsers arkitektur, gruppens sprog, teknologi, produkter og kunstneriske frembringelser" (Schein, 1994, s. 25).

Skuevcerdierne vil være det som medarbejderne og lederne selv fortæller, og de hjælper grupper til at styre adfærden, da de "er bestemmende for de dagligdags handleprincipper" (Schein, 1994, s. 26). Skueværdierne repræsenterer det organisationen selv fortæller om, hvordan den bør være, men ikke hvordan den rent faktisk er.

De grundlaggende antagelser er de dybere lag og essensen i den organisationskultur, der lægger til grund for værdier og handlinger. Mønstret af dem udgør som sagt kernen i kulturen. Antagelser opstår "[n]år en løsning på et problem virker gentagne gange", og til sidst bliver betragtet som en realitet, dvs. sandheden for medlemmerne af kulturen. (Schein, 
1994, s. 28). Det er usynlige, implicitte, adfærdsstyrende, taget-for-givet løsninger, og ubevidste for organisationskulturen selv. Derfor er de også svære at analysere, men det er muligt. Først identificeres artefakter og skueværdier, og ud fra en sortering og analyse af dem, kan man på den baggrund finde frem til de grundlæggende antagelser.

\section{Kulturen omkring anvendelsen af ESDH}

Analysen af implementeringsprojektet viste, at der er begået flere af de typiske projektfejl, som vi i dag kan se i bagklogskabens klare lys. Nogle af de faktorer der har haft indvirkning på kulturen omkring anvendelsen af ESDH i dag er følgende:

- Manglende vision og manglende fokus

- Manglende kommunikation mellem projektet og organisationen

- To parallelle systemer i brug - brug af både kopier og ESDH

- Utilstrækkelig tilpasning mellem IT og organisation

- Manglende håndtering af modstand mod implementeringen

Projektet havde også gode sider og overholdte nogle af de anbefalinger eksperterne i dag kommer med til IT-projekter. Projektet har bl.a. haft leder- og brugerinddragelse $\mathrm{i}$ form af styregruppe og superbrugere. De gode tiltag er dog blevet overskygget af uhensigtsmæssighederne. Figur 3 viser resultatet af den gennemførte kulturanalyse.

Kulturen er afbilledet som et mønster bestående af en række grundlæggende antagelser eller fundamentale træk ved kulturen. Antagelserne er grundlaget for værdier og handlinger og er bestemmende for hvordan virksomheden agerer. I dette tilfælde handler det om, hvordan caseobjektet agerer i forhold til anvendelsen af ESDH. Da de valgte at implementere ESDH skulle de lære det nye system at kende, nye måder at gøre tingene på samt nye måder at sagsbehandle på. Som det har vist sig, har de bibeholdt meget af det de lærte om sagsbehandling før ESDH, dvs. sagsbehandling i et ikke-elektronisk journalsystem.

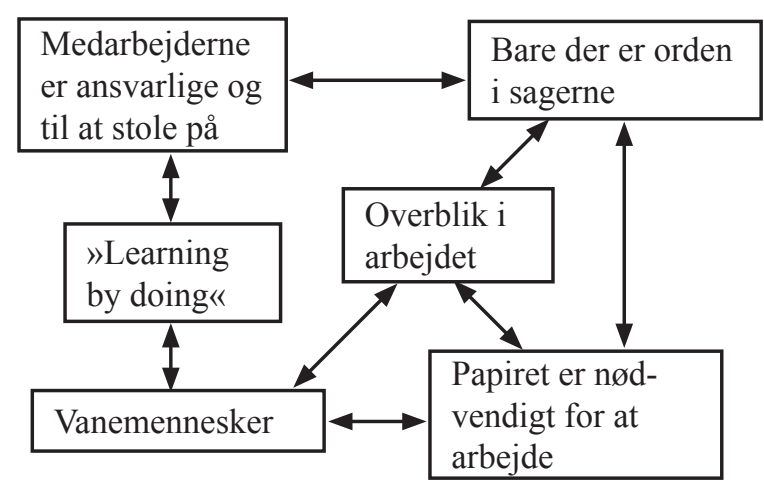

Figur 3. Resultatet af kulturanalysen hos caseobjektet - mønsteret af grundloeggende antagelser

Det som virksomheden har lært er først og fremmest, at medarbejderne er ansvarlige og til at stole på. Ansvar og tillid bliver flittigt anvendt af de interviewede ledere til at beskrive, hvordan de opfatter medarbejdernes anvendelse af ESDH. Hos ledelsen antages medarbejderne altså at være ansvarlige og til at stole på i relation til anvendelsen. Interviewene viste dog også, at de ansatte i virksomheden opfatter sig selv og andre som vanemennesker. At de kun kan arbejde, som de plejer.

Man lærer bedst at anvende ESDH "by doing". Det var primært ledelsens udsagn. Antagelsen demonstreres i organisationens ESDH-vejledning, som er tænkt som selvstudie, og i det faktum at en ny vejledning til ESDH-systemet har været $1 \frac{1}{2}$ år om at blive endeligt godkendt af ledelsen. Dermed viser ledelsen, at medarbejderne bedst lærer systemet, når de bruger det, og derfor er en vejledning tilsyneladende ikke af hastende vigtighed. Læring er stadig medarbejdernes eget ansvar og ledelsen har tillid til dem. Det vigtigste hos caseobjektet er, at der er orden i sagerne, dvs. at dokumenter er til at finde. Det er både ledelse og medarbejdere enige om. Men der er netop ikke orden i sagerne, når dokumenter i lang tid kun er at finde på den enkelte medarbejders private pc-drev. 
Endelig er det en overbevisning hos caseobjektet, at papir er nødvendigt for at arbejde, da det skaber overblik. I kulturen anses ESDH-systemet altså ikke som en nødvendighed, hvilket er det, som tegner anvendelsen af systemet.

Antagelsen om papir og overblik stammer tilbage fra dengang sagsbehandlingen skete ud fra originaldokumenter. Da virksomheden har dobbeltarbejdet, dvs. har kopieret posten i så mange år efter implementeringen af ESDH, er det implicit blevet understreget, at sådan arbejder man bedst. Ifølge Scheins organisationskulturteori opstår kultur blandt andet via ledere, som påfører medarbejderne værdier og antagelser. Når ledelsen i virksomheden ikke er klar i dens holdning til anvendelsen af ESDH, bliver det overført til medarbejderne. De udleder derefter, at ESDH åbenbart ikke er vigtigt nok. Det vigtigste er tilsyneladende blot, at dokumenterne bliver lagt ind på et eller andet tidspunkt. Derfor hænger kulturen omkring ESDH stadig fast i papirets betydning for overblik i arbejdet.

\section{Organisatorisk forankring af ESDH}

I forhold til kulturen omkring anvendelsen af ESDH er der et andet centralt begreb, som har præget undersøgelsens resultater. Det er forankring. I litteraturen (Christensen \& Kreiner, 1991; Bødker, Kensing \& Simonsen, 2000; Teknologirådet, 2001; Kræmmergaard Jensen, 1999) forklares begrebet forankring på mange forskellige måder. Ikke alle bruger termen forankring, men det er tydeligt at det er det der menes. Litteraturen taler om: Accept af projektet, forståelse for projektet, engagement og motivation i forhold til projektet, opbakning og fastgørelse til projektet, ejerskabsfølelse og forpligtigelse. Begrebet forankring forstås altså meget bredt. Man kan tale om forankring $\mathrm{i}$ to henseende, forankring $\mathrm{i} \mathrm{im}$ plementeringsprojektgruppen, eller forankring af implementeringsprojektet hos organisationen og dens medarbejdere. Sidstnævnte er det mest interessante her, da det i bund og grund drejer sig om, at organisationen, herunder ledelse og medarbejdere, ønsker at implementeringsprojektet bliver gennemført. For- stået på denne måde fører manglende forankring til modstand mod projektet, og modstand er naturligvis en stor barriere for implementeringen. Implementeringsprojekter, der ikke opbygger organisatorisk forankring, vil ifølge Walsham (1993) blive en fiasko.

Forankring er et af de der diffuse begreber, som det er svært at definere, og derfor svært at operationalisere. Alligevel mener jeg trygt at kunne sige, at ESDH ikke er fuldt ud forankret hos caseobjektet. Hos caseobjektet har ledelsens forankring haft, og har stadig, stor indvirkning på implementering og anvendelse af ESDH. Ledelsen har selvfølgelig taget beslutningen om at indkøbe ESDH, men det er alligevel præget af manglende forankring samt af manglende brug af, og kendskab til, ESDH-systemet. Det viser sig blandt andet ved, at de ikke har besluttet at stoppe kopiering af indkommende post, men har fortsat ordningen på grund af medarbejdernes protester. Der er generel manglende forankring af ESDH i virksomheden, det vil sige også hos medarbejderne. Teknologirådet (2001, s. 15) mener, at manglende forankring hos ledelsen ikke kan undgå at smitte af på medarbejdernes holdning. Det virker således logisk, at ledelsens manglende forankring fører til manglende forankring hos medarbejderne. Alle kan formentlig genkende situationer, hvor lederen udadtil forsøger at kommunikere et budskab, men bag kulisserne sender hun eller han et andet budskab. F.eks. kan ledelsen sige, at anvendelsen af ESDH er meget vigtigt for organisationen, men anvender ikke selv systemet. Det sender dermed et modstridende signal til medarbejderne. Medarbejdernes manglende forankring viser sig blandt andet ved anvendelsen af private drev på $\mathrm{pc}$ 'en til håndtering $\mathrm{af}$ dokumenter. Det demonstrerer tydeligt, at medarbejderne ikke ønsker at ESDH bliver organisatorisk implementeret.

\section{Implikationer af kulturen på anvendelsen af ESDH}

Kulturanalysen hos caseobjektet har bidraget til en forståelse af kulturen omkring anvendelsen af ESDH, og især den "irrationelle" kopiering af indgående post. Opsummerende kan det siges om kulturen, 
at caseobjektet hænger fast i tidligere lærte metoder til at udføre arbejdsopgaverne, og den er præget af manglende kendskab til og forankring i ESDH, hos såvel ledelsen som medarbejderne. ESDH anvendes dog i den daglige sagsbehandling - sagsdokumenter bliver lagt ind i systemet, om end forsinket - og kan derfor ikke udelukkende siges at have fejlet. Men med de uhensigtsmæssige arbejdsgange der fortsat eksisterer i organisationen, tyder det på at implementeringsprojektet ikke har haft held til at fjerne alle barrierer for indførelsen af et ESDH-system - og det påvirker anvendelsen i dag.

\section{Hvilken indflydelse har kulturen omkring anven- delsen af ESDH på videndeling?}

Den kultur der eksisterer hos caseobjektet omkring anvendelsen af ESDH betyder desværre, at mange af fordelene ved systemet falder bort. Det gælder eksempelvis videndeling, som er en af de gevinster ved ESDH, der fokuseres specielt meget på. Det skyldes at videndeling er med til at sikre virksomheder og organisationers effektivitet og konkurrencedygtigh ed.Videndeling kan bla. sikre at alle ikke sidder og opfinder den dybe tallerken hver gang, understøtte organisationer i at være effektive og ressourcebesparende samt $i$ at levere ydelser af høj kvalitet.

Videndeling vil i følge Davenport \& Prusak (1997) sige, at mennesker frivilligt gør information tilgængelig for andre. Viden befinder sig i individet, og den viden må nødvendigvis konverteres til organisatorisk viden, som så kan deles og skabe innovationer. Videndeling hos caseobjektet i relation til ESDH kan f.eks. være genbrug af afgørelser, sagsbegrundelser, godkendelser m.v. EDSH skulle gerne gøre det lettere at producere, gemme, søge og genbruge den information på tværs af organisationen. Det er systemerne også egnede til. ESDH kan være med til at skabe åbenhed og tilgængelighed til dokumenter. Med et begreb fra Nonaka \& Takeuchi (1995) kan man sige, at den eksplicitte viden kan deles på tværs af organisationen. Eksplicit viden er den viden, vi kan artikulere gennem sproget, hvorimod tavs viden er viden, som vi ikke umiddelbart er i stand til at for- midle, f.eks. vores overbevisninger, færdigheder eller knowhow.

Men tilgængelighed af sager er ikke lig med videndeling. Der skal arbejdes for at skabe en kultur, der deler viden. Hos caseobjektet synes uformel videndeling at være den herskende form for videndeling. Ud fra Nonakas terminologi vil det være det, der kaldes socialisering. Socialisering handler om mødet mellem flere individers tavse viden, dvs når individer gennem dialog og refleksion deler deres erfaringer og know-how. Det er muligvis den form for videndeling som medarbejderne hos caseobjektet foretrækker, og derfor kan de måske heller ikke forstå, hvorfor de skal dele viden gennem ESDH-systemet. Men Nonaka (1991) mener det er i samspillet mellem tavs og eksplicit viden, at viden bliver skabt. Det kalder Nonaka også for eksternalisering og internalisering. Caseobjektets kultur omkring sager (bl.a. har de artefakten "min sag") har sandsynligvis også en betydning for videndeling. Det kan forklare medarbejdernes ejerskab over dokumenter, og dermed deres manglende videndeling via eksplicit viden. Kulturen omkring anvendelsen af ESDH fremmer altså ikke videndeling hos virksomheden. Tværtimod, kan man sige, for hvis medarbejderne gentagne gange oplever, at kollegerne ikke anvender systemet, så forstærker det blot den nuværende kultur, hvor ESDH i stedet kommer til at virke som en barriere for adgangen til information.

\section{Hvad kan vi bruge viden om organisationskultur til?}

Som artiklen har lagt op til kan organisationskultur anvendes ved implementeringsprojekter og til at analysere anvendelsen af ESDH og andre IT-systemer. Sidstnævnte kan være en form for evaluering, som kan udnyttes til at sikre virksomheders udnyttelse af deres IT-investeringer. Det er min overbevisning, at en organisationskulturanalyse $\mathrm{i}$ forbindelse med implementering kan anskueliggøre de potentielle barrierer, der kan spille ind på den fremtidige anvendelse af systemet. Organisationskulturteori kan hjælpe os til at forstå, hvorfor det kan være så svært at gen- 
nemføre implementeringsprojekter (Fallon, s. 236) samt hvorvidt der er problemer i forhold til den efterfølgende anvendelse af systemerne. Teorierne kan også hjælpe til bl.a. at forstå hvorfor modstand mod forandring opstår - selv irrationel modstand og adfærd. Eller de kan forklare, hvorfor nogen tilsyneladende opfører sig ineffektivt, som i casestudiet. Kort sagt kan teori om organisationskultur hjælpe os til at forstå fejlslagne IT-projekter. Organisationskulturen kan også være en måde at få ting gennemført på, dvs. implementere systemer på (Fallon, s. 236). Ved at tage udgangspunkt i organisationskulturen kan man identificere de punkter, hvor barrierer kan opstå, og samtidig punkter hvor kulturen kan understøtte implementeringen af ESDH-systemet. Det kan f.eks. tænkes, at vi har en organisation, der er præget af en meget demokratisk kultur. I et sådan tilfælde nytter det ikke at vælge en top-down implementeringsstrategi, hvor det er ledelsen der dominerer projektet.

Forankring er et centralt begreb i forbindelse med implementering af ESDH, da det er herigennem at modstand mod implementeringen mindskes. I forbindelse med casestudiet blev det klart, at forankringen af ESDH-systemet både skal fastgøres igennem - og til - organisationskulturen. Som følge deraf kan organisationskulturen anvendes i forsøget på at skabe forankring. Laudon \& Laudon (1998, s. 80) mener, at hvis en forandring i teknologivariablen "truer" en kulturs grundlæggende antagelser, er sandsynligheden for modstand blandt medarbejderne stor. IT kan altså enten true eller understøtte organisationskulturen. Ofte anses organisationskulturen som værende mere magtfuld end informationsteknologien, og derfor undgår man helst forandringer i kulturen. I stedet anvendes IT til at støtte den eksisterende kultur. Det er der sådan set heller ikke noget galt i, på nær hvis organisationskulturen hindrer organisationens overlevelse i vidensamfundet.

\section{Hvad kan informationsspecialister bruge organi- sationskulturen til?}

Det vil i høj grad være relevant at anvende teorier om organisationskultur, når man som informationsspe- cialist står over for at skulle implementere, anvende og evaluere systemer til viden- og dokumenthåndtering i organisationer. Den organisationskulturteoretiske tilgang kan hjælpe os til at forstå, hvorfor det er så svært at få folk til at anvende systemerne. Flere jeg har talt med i bibliotekskredse ender altid med at sige: "Men folk bruger det ikke rigtig, hvordan får vi dem til at bruge systemerne?". Indenfor biblioteks- og informationsvidenskab ser vi systemerne som nødvendige for arbejdet, men sådan ser andre dem nødvendigvis ikke. Det må vi forstå når vi implementerer systemerne. Som implementeringskonsulent kan man bruge organisationskulturteori til at forstå sine egne grundlæggende antagelser i forhold til organisationens, og gennem en dybtgående forståelse for organisationen bedre imødekomme en eventuel modstand.

Digital forvaltning er et område som informationsspecialister kan bidrage til. Men i den forbindelse kommer vi ikke uden om et emne som organisationskultur. Årsagen er, at de offentlige institutioner ikke kan nøjes med at scette strøm til eksisterende arbejdsgange. De er nødt til at effektivisere og kvalificere arbejdsprocesserne. Hvis vi skal hjælpe dem med workflowsanalyser, struktur mv., skal vi samtidig sikre os, at kulturen tilpasses digitaliseringen. Ellers nytter det ikke.

\section{Noter}

1) Undersøgelsen foregik hos Miljøkontrollen, men virksomheden omtales i artiklen som 'caseobjektet'

\section{Litteratur}

Andersen, I. (1997): Den skinbarlige virkelighed: Om valg af samfundsvidenskabelige metoder. Frederiksberg: Samfundslitteratur.

Andersen, K.V.; Friis, C. S.; Hoff, J., \& Nicolajsen, H. W. (Eds.) (1999). Informationsteknologi, organisation og forandring : Den offentlige sektor under 
forvandling. København: Jurist- og Økonomforbundets Forlag.

Bødker K., Kensing, F. \& Simonsen, J. (2000). Professionel IT-forundersøgelse : Grundlaget for boredygtige IT-anvendelser. København: Samfundslitteratur.

Christensen, S. \& Kreiner, K. (1991). Projektledelse i løst koblede systemer : ledelse og loring i en ufuldkommen verden. København: Jurist- og Økonomforbundets Forlag.

Cooper, R.B. (1994). The inertial impact of culture on IT implementation. Information \& Management 27 , s. $17-31$.

Davenport, T.H. \& Prusak, L. (1997). Information ecology : mastering the information and knowledge environment. New York: Oxford University Press.

Deloitte \& Touche Consulting Group (1998). Danske erfaringer med implementering af integrerede informationssystemer. Danmark: Deloitte \& Touche.

Eason, K. (1988). Information technology and organisational change. London: Taylor \& Francis.

Fallon, H. (1995). How to implement information systems and live to tell about it. New York: Wiley.

Forskningsministeriet (1997). I gang med digital forvaltning. København: Forskningsministeriet. Lokaliseret den 20. februar 2004 på World Wide Web: http: //www.fsk.dk/fsk/publ/1997/igang/igang.htm.

Gorman, G.E \& Clayton, P. (1997). Qualitative research for the information professional : a practical handbook. London: Library Association Publishing.

Hatch, M.J. (2001). Organisasjonsteori: Moderne, symbolske og postmoderne perspektiver. Oslo: Abstrakt Forlag.
Hertzum, M. (2002). Organisational implementation : a complex but under recognised aspect of information-system design. NordiCHI 2002: Proceedings of the second Nordic conference on human-computer interaction (Aarhus, Denmark, October 19-23, 2002). New York: ACM Press s. 199-202.

Hoffman, N \& Klepper, R. (2000). Assimilating new technologies: The role of organizational culture. Information Systems Management 17 (3), s. 36-42.

Højmark Larsen, V. (2003). Anvendelsen af Elektronisk Sags- og DokumentHåndtering i Miljøkontrollen : Analyse af kulturen omkring anvendelsen af ScanJour i Miljøkontrollen. Danmarks Biblioteksskole. (Speciale i biblioteks- og informationsvidenskab).

Kræmmergaard Jensen, P. (1999): IT-implementering og forandringsledelse. International Business Economics, Reprint Series, 18. Lokaliseret den 20. februar 2004 på World Wide Web: http:// www.business.auc.dk/ivo/papers/rep/rps18.pdf .

Kwon, T.H. \& Zmud, R.W. (1987). Unifying the fragmented models of information systems implementation. Boland, R.J. \& Hirschheim, R. (eds). Critical Issues in information systems research (s. 227253). New York: John Wiley \& Sons.

Laudon, K.C. \& Laudon, J.P. (2000). Management Information Systems : new approaches to organization and technology. Upper Saddle River: Prentice Hall. 5. udg.

Leavitt, H.J. (1965). Applied organizational change in industry : structural, technological and humanistic approaches. March, J.G. (ed). Handbook of Organizations (s. 1144-1170). Chicago: Rand McNally \& Company.

Nonaka, I. \& Takeuchi, H. (1995). The Knowledge creating company. New York: Oxford University Press. 
Projekt Digital Forvaltning (2002): Organisatoriske aspekter af et ESDH-projektforløb : en tjekliste. København: Projekt Digital Forvaltning. Lokaliseret den 20. februar 2004 på World Wide Web: http://www.e.gov.dk/sitemod/upload/Root/ Projekter/ESDH.pdf set d.20/2-2004].

Robey, D. \& Azevedo, A. (1994). Cultural Analysis of the Organizational Consequences of Information Technology. Accounting, Management and Information Technologies 4 (1), 23-37.

Schein, E.H. (1994). Organisationskultur og ledelse. København: Forlaget Valmuen. 2. udg.
Steinmark, C. \& Zangenberg, H. (1998). Elektronisk dokumenthåndtering : jura, metoder, eksempler. København: Teknisk forlag.

Teknologirådet (2001). Erfaringer fra statslige ITprojekter : hvordan gør man det bedre? Rapport og anbefalinger fra en arbejdsgruppe under Teknologirådet. København: Teknologirådet (Teknologirådets rapporter; 3) Lokaliseret den 13 maj 2003 på World Wide Web http://www.tekno.dk/pdf/projekter/p01 Rapport_it_proj.pdf

Walsham, G. (1993). Interpreting information systems in organizations. Chichester: John Wiley \& Sons. (John Wiley series in information systems) 